\title{
Geoelectric Investigation Of Deghele Community In Warri South West L.G.A, Delta State, Nigeria
}

\author{
Atakpo, E. A. \\ Department of Physics, Delta State University, Abraka
}

\begin{abstract}
A geoelectric investigation has been conducted at Deghele Community, Warri South West L.G.A, Delta State, Nigeria. The Vertical Electrical Sounding (VES) method was adopted with maximum current electrode separation $(A B)$ of $600 \mathrm{~m}$. The interpretation revealed four to six geoelectric layers which include Topsoil, Silty sand, Clay and Sand. The topsoil has thickness varying from about 1.43 to $3.8 \mathrm{~m}$ while its resistivity values vary from 2.23 to $131 \Omega \mathrm{m}$. The second and third geoelectric layers are composed of Silty sand/sand. This layer which is saline has resistivity values ranging from 2.23 to $78 \Omega \mathrm{m}$ and thickness varying from 7 to $20 \mathrm{~m}$. The low resistivity values may be as a result of tides propagating saline sea water inland through the interconnecting creeks. The fourth geoelectric layer is composed of sand with resistivity values varying from 1121 to $2796 \Omega \mathrm{m}$. This layer forms the aquifer unit and has a maximum thickness of about $170 \mathrm{~m}$ and at a depth of about $180 \mathrm{~m}$. The sixth layer terminated in a clay formation with resistivity values of about 65 $\Omega m$. This study has provided an insight to the subsurface disposition of the aquifer systems and delineated areas for groundwater development programme in Deghele community.
\end{abstract}

Key Words- Geoelectric, aquifer, resistivity, Deghele community

\section{Introduction}

Groundwater exploration most often results in failed boreholes when these boreholes are drilled without prior geophysical investigation of the area of interest in order to map the location, geologic sequence and depth where prolific aquifer could be reached and tapped. Such ventures could be more costly in the riverine areas where access to these communities is difficult. Hence embarking on borehole projects would involve the transportation of the equipment with outboard engines over long distances through meandering river subchannels and creeks. In order to avoid such an occurrence, hydrogeophysical investigation was conducted at Deghele, a riverine Community in Warri South West L.G.A, Delta State, using the Geoelectric survey.

The Geoelectric survey using the vertical electrical sounding (VES) technique involves the measurement of apparent resistivity of subsurface as a function of depth or position. This method largely depends on the porosity, ionic content of pore spaces, permeability and clay mineralization. It has been found suitable for determining freshwater bearing formation $[1,2,3,4,5,6]$. The geoelectric method has also proved successful in the mapping of saltwater interfaces in many different hydrogeologic settings[7,8]. This study was undertaken with the aim of delineating the subsurface geoelectric sequence and determining the layer geoelectric parameters, evolve a general geologic sequence of the area and determine the aquifer units beneath the surface and their depth of occurrence.

\subsection{Theory}

The generalized form of electrode configuration in resistivity survey is shown in Figure 1.

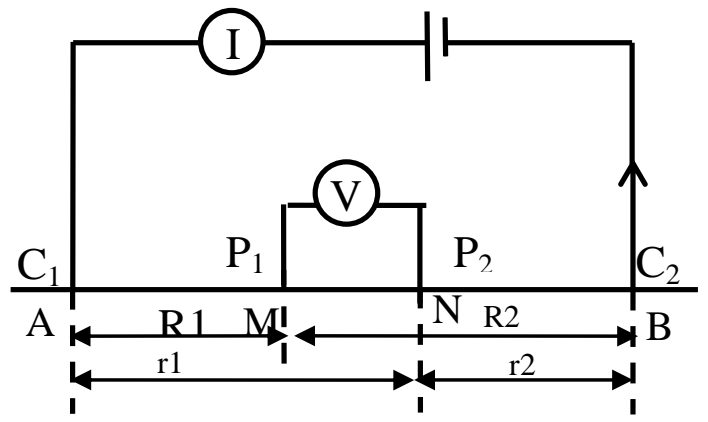

Figure 1: Generalized form of Electrode Configuration

The potential at the electrode $\mathrm{M}$ and $\mathrm{N}$ are, 


$$
\begin{gathered}
V_{M}=\frac{\rho_{a} I}{2 \pi}\left(\frac{1}{R 1}-\frac{1}{R 2}\right)--------(1) \\
V_{N}=\frac{\rho_{a} I}{2 \pi}\left(\frac{1}{r 1}-\frac{1}{r 2}\right)--------(2)
\end{gathered}
$$

However the measured parameter is the difference in potential between $\mathrm{M}$ and $\mathrm{N}$, from equations 1 and 2,

$$
\Delta V_{M N}=\frac{\rho_{a} I}{2 \pi}\left[\left(\frac{1}{R 1}-\frac{1}{R 2}\right)-\left(\frac{1}{r 1}-\frac{1}{r 2}\right)\right]--------(3)
$$

Hence

$$
\begin{aligned}
& \rho_{a}=\frac{2 \pi \Delta V_{M N}}{I_{1}}\left[\left(\frac{1}{R 1}-\frac{1}{R^{2}}\right)-\left(\frac{1}{r 1}-\frac{1}{r 2}\right)\right]^{-1}=K R_{e s} \\
= & 2 \pi\left[\frac{1}{R 1}-\frac{1}{R 2}-\frac{1}{r 1}+\frac{1}{r 2}\right]
\end{aligned}
$$

Where $\mathrm{K}$ is

and

$$
R_{e s}=\frac{\Delta V_{M N}}{I}
$$

For the Schlumberger array used in this survey $\mathrm{MN}=\mathrm{b}$ and the distance from the current electrode on either side to the center of the potential electrode is given as ' $a$ ' where $a \geq 5 b$, thus,

$$
K=\frac{\pi a^{2}}{b}\left[1-\frac{b^{2}}{4 a^{2}}\right] \quad \text { and } \quad \rho_{a}=\frac{\pi a^{2}}{b}\left[1-\frac{b^{2}}{4 a^{2}}\right] R_{e s}
$$

$\mathrm{K}$ is the geometric factor obtained from the field configuration and $\rho_{a}$ is the apparent resistivity obtained from the field resistivity data [9].

\section{Location Of Study Area}

Deghele Community is located in Warri South West Local Government area at Longitude of $005^{\circ}$ 9.147' E and Latitude $05^{\circ} 44.3383^{\prime} \mathrm{N}$. It is located within the coastal creeks between the Benin River and the Escravos River (Fig.2) that links Warri and Escravos. The vegetation is characterised by mangrove forests and rain forests. The Mangrove Swamps are low lying, generally at less than about $5 \mathrm{~m}$ above sea level, drained and crisscrossed by tidal creeks. The study area is well drained by rivers and creeks and located in an estuarine environment where the surface and near surface ground water is brackish to saline with a windy tropical climate. Rain fall is all year round and the annual ten year mean is about $2652 \mathrm{~mm}$ while the mean daily temperature is $31.2^{\circ} \mathrm{C}[10]$.

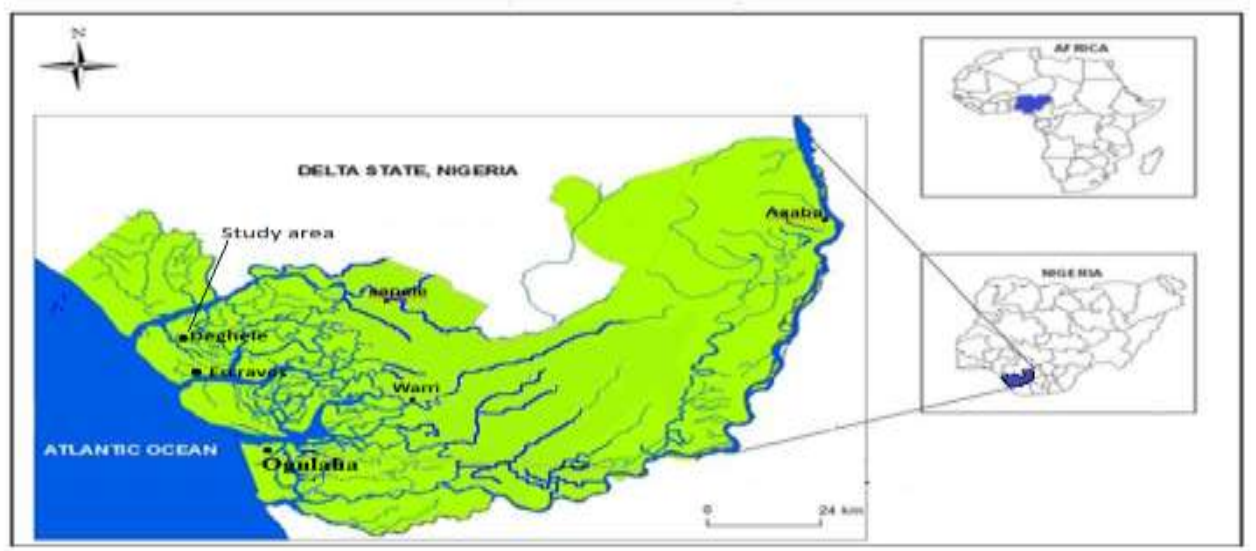

Figure 2. Map of Delta State, Nigeria showing study area. 


\section{Geology Of Study Area}

The sedimentary environments and morphological features of the Niger Delta are much studied and summary descriptions may be found in [11] and [12]. The Niger Delta consist of three main Tertiary stratigraphic units overlain by Quaternary deposits [11]. The base is the Akata Formation (Palaeocene to Eocene) comprising mainly of marine shales and sand beds. The Agbada Formation (Eocene to Oligocene) is the intermediate paralic sequence consisting of interbedded sands and shales that serve as both sources and reservoir rocks, laid down in brackish-marine environments. The youngest Benin Formation (Oligocene to Recent) is a prolific aquifer comprising fluviatile gravels and sands.The stratigraphic units thicken basin wards across a series of growth faults, with associated rollover anticlines that serve as the predominant hydrocarbon traps in the region. The Quaternary-Recent sediments that overlie the Benin Formation consist of grey coloured fine-medium grained sands that dominate the beaches which flank the Atlantic Ocean (Fig.3). Darker coloured and thin layered silts are more dominant landwards in the mangrove swamps. Sands and silts are underlain in places by lensoid clays. These sediments are the recent and modern expression of the Benin Formation.

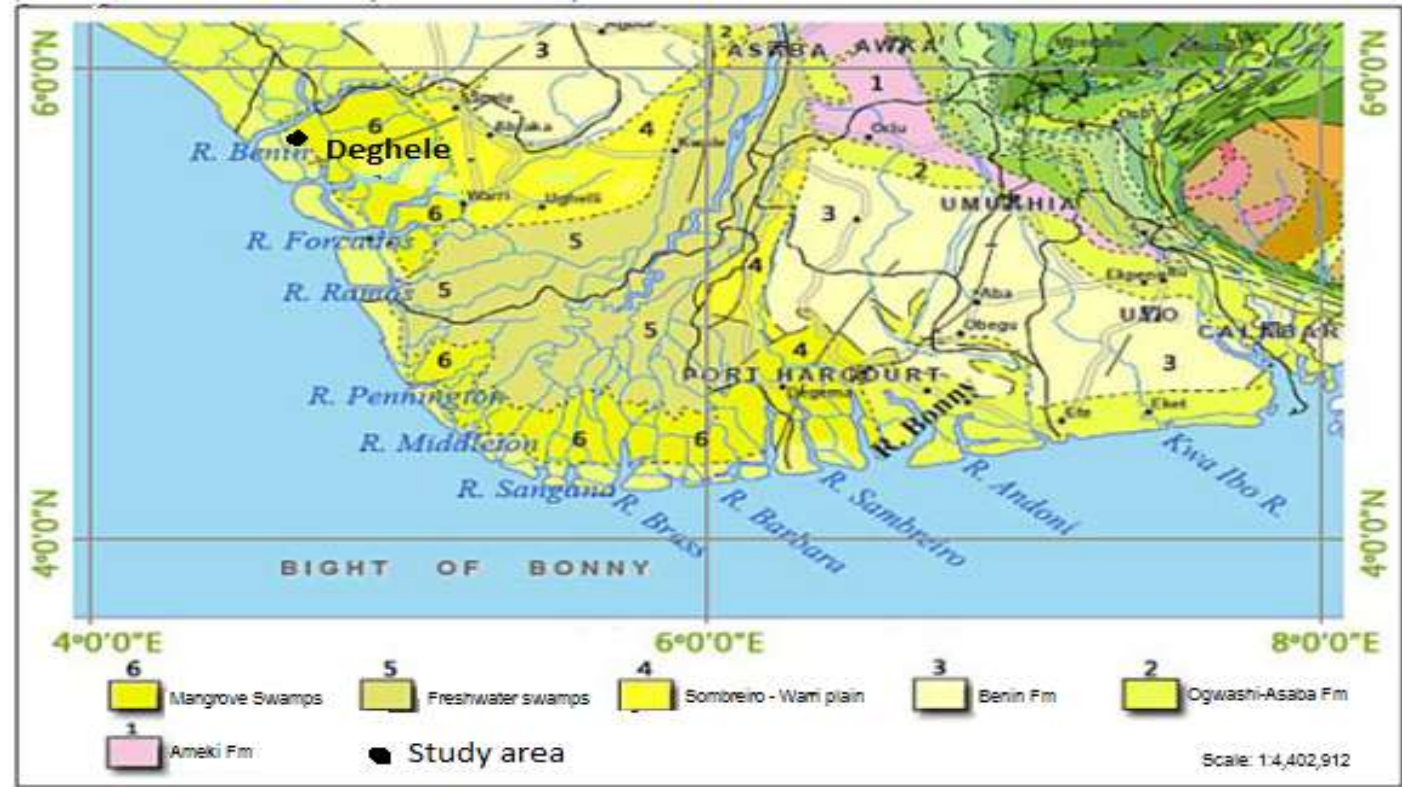

Figure 3. Geological Map of Niger Delta showing the areal distribution of the Mangrove Swamp and the Benin Formation [13].

\section{Methodology}

The Schlumberger depth sounding technique was adopted for the data acquisition. In this method, two short metallic stakes (electrodes) were driven about one foot into the earth to apply current to the ground. Two additional electrodes were used to measure the earth voltage (or electrical potential) generated by the current. The depth of investigation is a function of the electrode spacing and is generally about $20 \%$ to $40 \%$ of the outer electrode spacing, depending on the earth resistivity structure. The greater the spacing between the outer electrodes, the deeper the electric current would flow in the earth, hence the greater the depth of exploration. Vertical Electrical Sounding (VES) positions with maximum electrode separation of $600 \mathrm{~m}$ were occupied. The resistivity values were obtained using the ABEM SAS 4000 Terrameter. Other equipment employed include: metal electrodes, hammers, meter rule and four reels of wire. Also Global Positioning System (GPS) was used to determine the longitude, latitude and elevation of the VES locations of the study area.

\section{Results And Discussion}

The results of the resistivity survey are presented as resistivity curves. The curves interpreted using the Winglink inversion software [14] were the QHAK, QHAA, AAA, KHK, HKQ and QHK type curves (Fig. 4). Two geoelectric sections were drawn along traverse 1 and 2 in the East - West directions.

The geoelectric section along traverse 1 in Fig. 5 shows six geoelectric layers composed of topsoil, silty sand, sand and clay. The topsoil has thickness varying from about 1.43 to $3.8 \mathrm{~m}$ while its resistivity values vary from 2.23 to $105 \Omega \mathrm{m}$. The second and third geoelectric layers are composed of Silty sand/sand. The resistivity value range from 2.23 to $50 \Omega \mathrm{m}$ and thickness varying from 7 to $9 \mathrm{~m}$. The low resistivity values may be as a result of tides propagating saline sea water inland through the interconnecting creeks. The fourth and fifth geoelectric layers are composed of sand with resistivity 1121 to $2796 \Omega \mathrm{m}$. This layer forms the aquifer unit and 
has a maximum thickness of about $170 \mathrm{~m}$ and at a depth of about $180 \mathrm{~m}$. The sixth layer terminated in a clay formation with resistivity values of about $65 \Omega \mathrm{m}$ at a depth of $180 \mathrm{~m}$.

The geoelectric section along traverse 2 in Fig. 6 shows four geoelectric layers composed of topsoil, silty sand and sand. The topsoil has thickness varying from about 2 to $8 \mathrm{~m}$ while its resistivity values vary from 71 to $131 \Omega \mathrm{m}$. The second and third geoelectric layers are composed of Silty sand/sand. The resistivity value range from 9 to $78 \Omega \mathrm{m}$ and thickness varying from 12 to $20 \mathrm{~m}$. The fourth and fifth geoelectric layers are composed of sand with resistivity 505 to $1120 \Omega \mathrm{m}$.
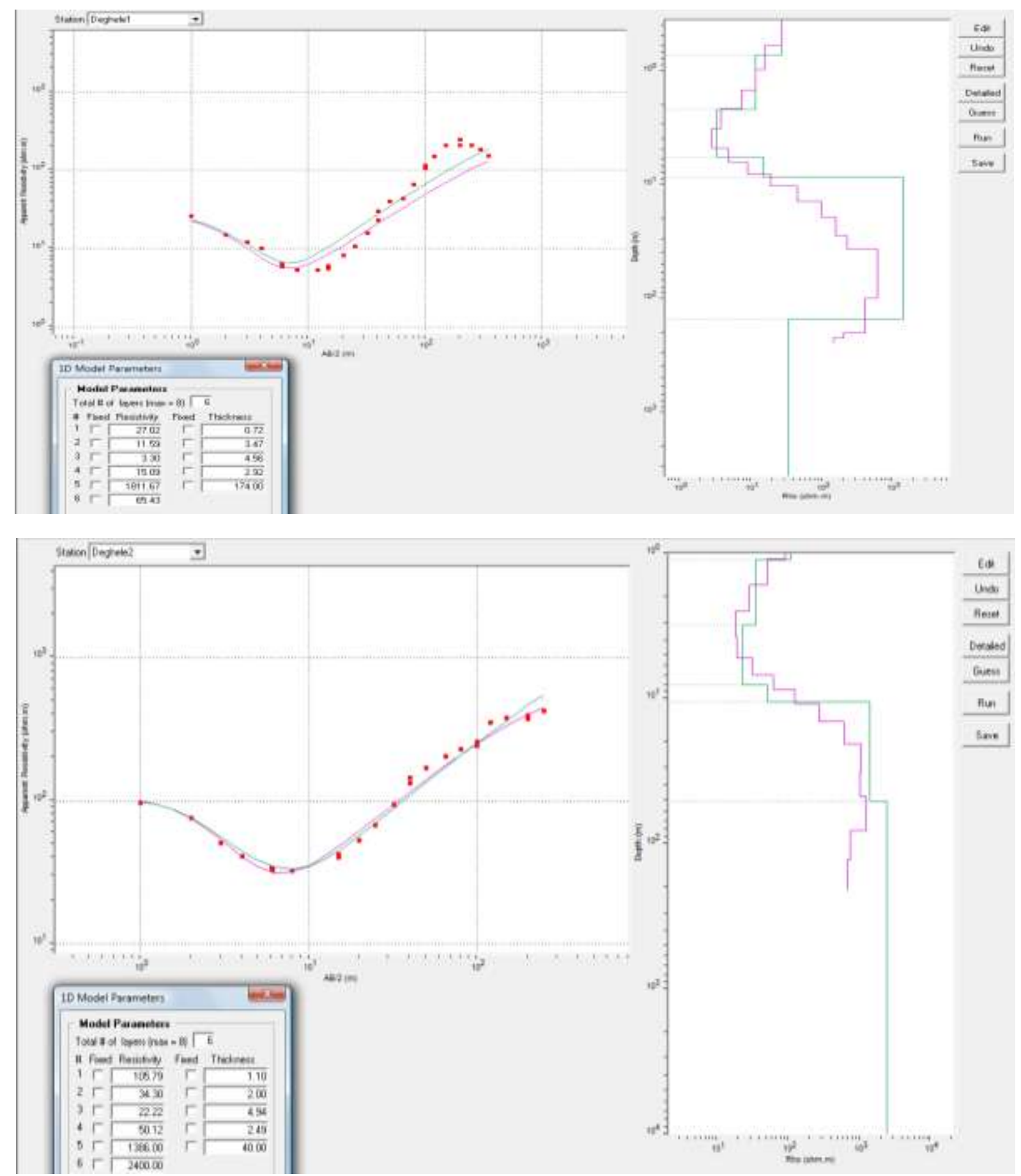

Figure 4. Typical depth sounding curves for the area of study 


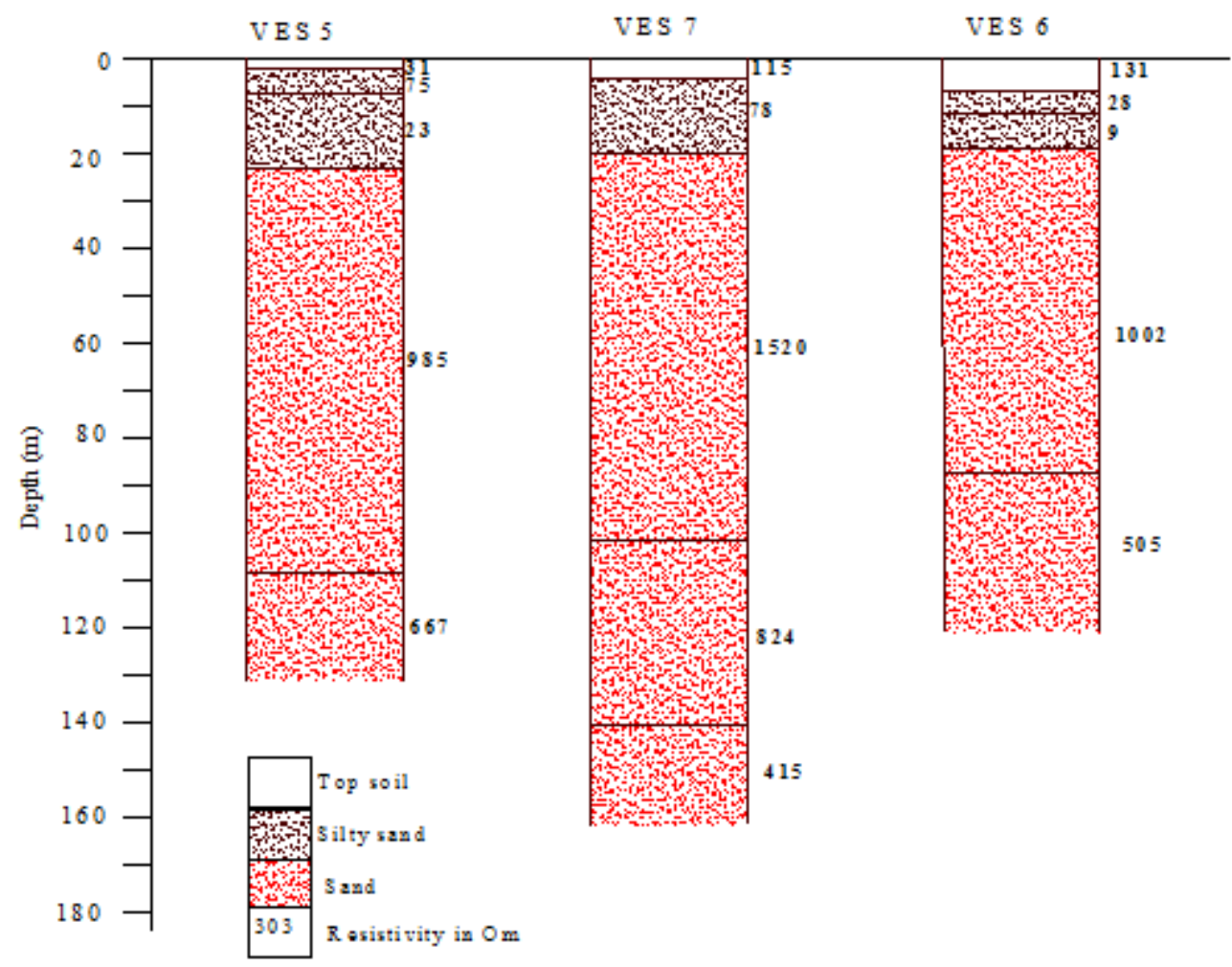

Figure 6. The Geoelectric Section along traverse 2

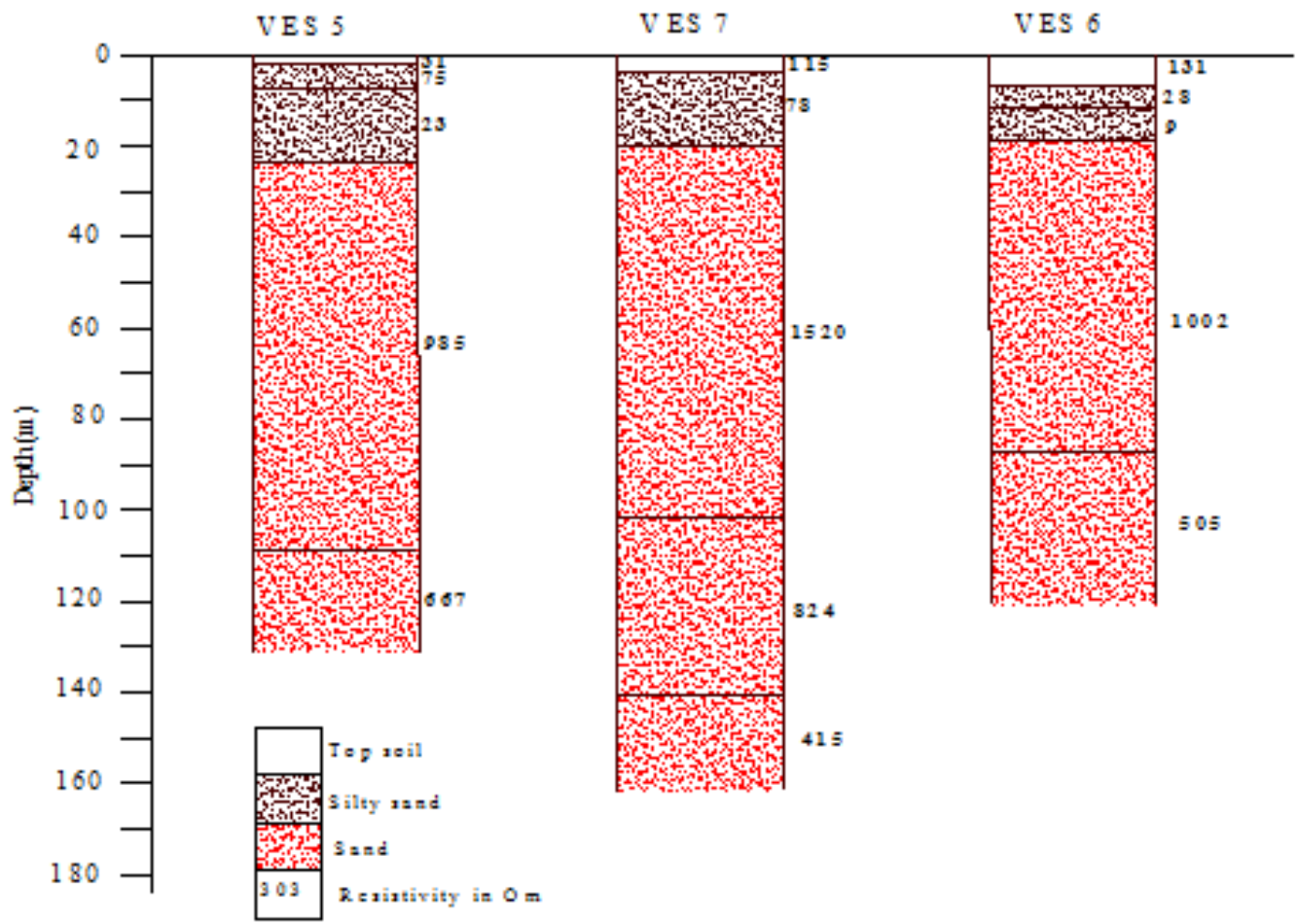

Figure 6. The Geoelectric Section along traverse 2 


\section{Conclusion}

This paper describes the use of surface electrical resistivity survey in delineating the subsurface formation in Deghele community. The survey involved a total of 7 Schlumberger vertical electrical soundings (VES). The results of the survey have enabled the delineation of the aquifer unit in the study area. Four to six geoelectric layers namely the topsoil, silty sand, sand and clay were delineated in the area. The resistivity of the layers varied from 2.23 to $2796 \Omega \mathrm{m}$. The low resistivity values varying from 2.23 to $78 \Omega \mathrm{m}$ observed in the first three shallow layers to a depth of about $20 \mathrm{~m}$ may be as a result of saline water intrusion. Based on the resistivity parameters and the overall thickness of geoelectric layers overlying the aquifer units, the near surface aquifer systems in the study area are generally not suitable for boreholes. It would be recommended that the boreholes may be drilled to tap from the aquifer from the depth of $25 \mathrm{~m}$ to about $180 \mathrm{~m}$ where clay may be intercepted. This study has provided an insight to the subsurface disposition of the aquifer systems and delineated areas for groundwater development programme in Deghele community.

\section{References}

[1] Zohdy, A.A.R; P. Martin and R.J. Bisdorf A Study of Seawater Intrusion using Direct-Current Soundings in the Southeastern part of the Oxnard Plain, California. U.S. Geological Survey open file report. 93-523 1993, 139.

[2] Oladapo, M.I, Mohammed, M.Z, Adeoye, O.O and B.A. Adetola. Geoelectrical investigation of the Ondo State Housing Corporation Estate, Ijapo Akure, Southwestern Nigeria. Journal of mining and geology 40(1), 2004, 41- 48.

[3] Ayolabi, E.A. Geoelectric Evaluation of Groundwater Potential: A case Study of Alagba Primary School, Akure Southwest Nigeria Nigeria. Journal Geological Society of India 66, 2005, 491-495.

[4] Atakpo, E.A. and E.A. Ayolabi. Evaluation of aquifer vulnerability and the protective capacity in some oil producing communities of western Niger Delta. Environmentalist, Springer. 2008, DOI 10.1007/s 10669-008-9193-3.

[5] Omosuyi, G.O., J.S. Ojo, and M.O. Olorunfemi. Geoelectric Sounding to Delineate Shallow Aquifers in the Coastal Plain Sands of Okitipupa Area, Southwestern Nigeria. The Pacific Journal of Science and Technology, 9(2), 2008, 562-577.

[6] Lenkey, L., Z. Hamori, and P. Mihalffy. Investigating the Hydrogeology of a Water-Supply area using Direct-Current Vertical Electrical Soundings. Geophysics. 70(4): 2005, H1-H19.

[7] Olorunfemi, M.O.. Computer model studies of IP and resistivity response of a typical array depth sounding. Geoexploration, 23, 1985, 193-205.

[8] Adepelumi ,A. A., B. D. Ako., T. R. Ajayi., O. Afolabi and E. J. Omotoso. Delineation of saltwater intrusion into the freshwater aquifer of Lekki Peninsula, Lagos, Nigeria. Environ Geol, Springer-Verleg. 2008. DOI 10.1007/s00254-008-1194-3.

[9] Ayolabi E.A, Atakpo E.A, Adeoti L, Otobor E.C and Arerin T. Groundwater Quality Assessment Using Predriling Electrical Measurements. Journal of environmental Hydrology, 17(15) 2009. 1-12.

[10] Nigerian Meteorological Agency. Warri Meteorological Bulletin. In: National Meteorological Report, 2003.

[11] Short, K. C. and A. J., Stauble,. Outline of Geology of Niger Delta, Bull. AAPG .,(51)5, 1967, 761-779.

[12] Asseez, L.O.. Review of the stratigraphy, sedimentation and structure of the Niger Delta. In: CA Kogbe (ed), Geology of Nigeria. (Rockview, Jos. 1989) 311-334.

[13] Akpoborie A. I. and K.E. Aweto.. Groundwater conditions in the mangrove swamps of the western Niger Delta: Case study of the Ughoton area, Delta State, Nigeria. Journal of Environmental Hydrology. 20(6) 2012, 1-14.

[14] Winglink Integrated interpretation software. Version 1.62.08.Geosystem corporation, Milan. 2003. 